\title{
Patterns of Variation in Alkamides and Cichoric Acid in Roots and Aboveground Parts of Echinacea purpurea (L.) Moench
}

\author{
Luping Qu, Ying Chen, Xiping Wang, ${ }^{1}$ and Richard Scalzo \\ Gaia Herbs, Inc., 108 Island Ford Road, Brevard, NC 28712
}

\author{
Jeanine M. Davis \\ Mountain Horticultural Crops Research and Extension Center, North Carolina \\ State University, 455 Research Drive, Fletcher, NC 28732
}

Additional index words. medicinal plants, phytochemicals, HPLC, correlation, plant breeding

\begin{abstract}
We investigated patterns of variation in alkamides and cichoric acid accumulation in the roots and aboveground parts of Echinacea purpurea $(\mathrm{L}$.) Moench. These phytochemicals were extracted from fresh plant parts with $60 \%$ ethanol and quantified by high performance liquid chromatography (HPLC) analysis. Concentrations of alkamides and cichoric acid were measured on a dry-weight basis $\left(\mathrm{mg}^{\left.\cdot-\mathrm{g}^{-1}\right)}\right.$. For total alkamides, concentrations among individual plants varied from 5.02 to 27.67 (mean $=14.4 \%)$ in roots, from 0.62 to $3.42($ mean $=1.54)$ in nearly matured seed heads $(\mathrm{NMSH})$, and 0.22 to 5.25 $($ mean $=0.77)$ in young tops (about $1 / 2$ flower heads, $1 / 4$ leaves, and $1 / 4$ stems). For cichoric acid, concentrations among individual plants varied from 2.65 to 37.52 (mean $=8.95$ ), from 2.03 to $31.58($ mean $=10.9)$, and from 4.79 to $38.55($ mean $=18.88)$ in the roots, the NMSH, and the tops, respectively. Dodeca-2E, $4 \mathrm{E}, 8 \mathrm{Z}, 10 \mathrm{E}$-tetraenoic acid isobutylamide and dodeca-2E, 4E, 8Z, 10Z-tetraenoic acid isobutylamide (alkamides 8/9) accounted for only $9.5 \%$ of the total alkamides in roots, but comprised $87.9 \%$ in the NMSH, and $76.6 \%$ in the young tops. Correlations of concentrations of alkamides or cichoric acid between those of roots and those of the NMSH were not statistically significant, and either within the roots, the NMSH, and the young tops. However, a significant negative correlation was observed between the concentration of cichoric acid in the roots and in young tops, and a significant positive correlation was observed between total alkamide concentration in the roots and cichoric acid concentration in the young tops. These results may be useful in the genetic improvement of $E$. purpurea for medicinal use.
\end{abstract}

Belonging to the composite family (Asteraceae), Echinacea, commonly known as purple coneflower, is a perennial, herbaceous plant native to eastern North America. A detailed morphological classification of Echinacea was provided by McGregor (1968) and recently revised by Binns et al. (2002a) by using morphological as well as numerical and statistical methods. According to McGregor (1968) there are 11 taxa in Echinacea including 9 species and two botanical varieties. In the revision by Binns et al. (2002a) 2 subgenera and four species were recognized. In this report McGregor's (1968) taxonomy is followed.

As an herbal medicine, Echinacea has long been used by Native Americans for many rem-

\footnotetext{
Received for publication 21 Dec. 2004.Accepted for publication $19 \mathrm{Feb}$. 2005. This publication is made possible by the Small Business Innovation Research program of the U.S. Department of Agriculture, grant number \# 2004-33610-14336 and by grant number 1R44AT771-01 from the National Center for Complementary and Alternative Medicine. Mention of commercial brand names does not constitute an endorsement of any product by the authors or their employers. The authors thank Mark P. Widrlechner and James F. Hancock for their critical reviews of this manuscript.

'To whom reprint requests should be addressed; e-mailx0w@gaiaherbs.com.
}

for the overall yield of phytochemicals.

Three groups of phytochemicals, caffeic acid derivatives, polysaccharides, and lipophilic alkamides, are the most likely candidates responsible for the genus's medicinal properties (Bone, 2004). Of the caffeic derivatives, cichoric acid is thought to be important based on the results of immunological and pharmacological studies (Bauer, 1999, 2000; McDougall et al., 1998). Alkamides as a group have demonstrated immunological activity both in vitro and in vivo (Bauer et al., 1988a; Goel et al., 2002). Most recently, in a randomized, double-blind, placebo-controlled clinical trial, Goel et al. (2004) found that liquid extracts made from freshly harvested flowering tops of $E$. purpurea, standardized to contain alkamides, cichoric acid, and polysaccharides at concentrations of $0.25,2.5$, and $25.5 \mathrm{mg} \cdot \mathrm{mL}^{-1}$, respectively, effectively treated the common cold in adults.

Of the three Echinacea taxa typically used in herbal medicine, E. purpurea is the most widely utilized and cultivated species, accounting for $80 \%$ of commercial production ( $\mathrm{Li}, 1998$ ). Given the large market and evidence for human health benefits of Echinacea, it would be valuable to increase concentration of the bioactive components in this plant through breeding and selection. Since both roots and aboveground parts are used in extract preparation ( $\mathrm{Li}, 1998)$, it would also be interesting and potentially useful to evaluate relationships between roots and aboveground parts for production of these phytochemicals, as well as for variation among individual plants.

Previous researchers (Binns et al., 2002b; Perry et al., 2004; Stuart and Wills, 2000) have reported that significant variation in caffeic acid and alkamide content was observed among different plants, at different developmental stages, and across various locations. However, these studies had certain limitations. For example, samples were collected from plants not grown under typical field cultivation conditions (Binns etal., 2002b); bulk samples were used for evaluation of the effects of seasonal or locational differences (Perry et al. 2004; Stuart and Wills, 2000 ), or the methods for sample collection were not provided (Letchamo et al., 2002). Therefore, it is difficult to apply the results of these studies to the practical matters of selection and genetic improvement.

The goal of this investigation was to evaluate variation in the production and concentration of alkamides and cichoric acid among individual $E$. purpurea plants under field cultivation conditions and determine correlations between these two classes of phytochemicals within and among different plant parts.

\section{Materials and Methods} and its potential benefits to human health, relatively little effort has been directed towards the genetic improvement of Echinacea for medicinal purposes. Breeding E. purpurea for ornamental use has been conducted in Europe (Galambosi, 2004) and on a small scale in the United States (Chicago Botanical Garden, 2001) and Australia (Hawks, 2002). Letchamo et al.(1999) reported that selections were made in E. purpurea for both ornamental value and
Echinacea purpurea seedlings were established in a greenhouse from seeds purchased from five commercial sources (Companion Plants, Athens, Ohio; Johnny's Selected Seeds, Albion, Maine; Prairie Nursery, Westfield, Wis.; Prairie Moon Nursery, Winona, Minn.; and Wind River Seed, Manderson, Wyo.) and transplanted into a field of sandy loam 
soil $(\mathrm{pH} \approx 6.0)$ on the certified organic Gaia Farm (Brevard, North Carolina) in late March 2004. Beds of $90 \mathrm{~cm}$ wide and $30 \mathrm{~cm}$ high were prepared before transplanting. Plants were spaced $30 \mathrm{~cm}$ apart within and between rows, with each bed containing three rows. The experimental design was a randomized complete block with three replications each of 30 plants. There was no fertilization before or after transplanting and no artificial irrigation during cultivation. Plants started to flower in mid-August 2004. On average, the final height of the plants at the end of the first growing season was about $110 \mathrm{~cm}$.

On 11 Oct. 2004, roots and nearly mature seed heads (NMSH, anthesis of disk flowers finished, with styles green to yellowish) were randomly sampled from 30 plants across the blocks with two plants from each replication. Root samples were nondestructively collected by digging and loosening the soil from one side of the root system and cutting off about $6 \mathrm{~g}$ of root material. One seed head was harvested from each of the plants. All samples were placed in plastic bags and taken immediately back to the laboratory. Another 30 plants were randomly sampled on 14 Oct. 2004 for roots and young tops. The root was sampled as described above. The young tops, which consisted of unopened flower heads (the ligules of ray flowers were about $1 \mathrm{~cm}$ in length) on stems with leaves, were recently produced from the root crowns.

Roots were thoroughly washed with tap water and blotted dry on paper towels. The samples were cut into small pieces (about $2 \mathrm{~mm}$ wide initial cuts and randomly cut thereafter) with scissors. The young tops consisted of about $1 / 2$ flower head, $1 / 4$ stem, and $1 / 4$ leaves by weight. Moisture content was measured with an IR-200 Moisture Analyzer(Denver Instrument, Arvada, Colo.). Three grams each of the cut samples were placed into 125-mL Erlenmeyer flasks. After adding $40 \mathrm{~mL} \mathrm{60 \%} \mathrm{grain} \mathrm{ethanol,}$ the flasks were ultra-sonicated for $3 \mathrm{~h}$ in a water bath. Each extract was centrifuged at 3200 rpm for $8 \mathrm{~min}$ and the supernatant was used for high performance liquid chromatography (HPLC) separation.

HPLC analytical equipment included a Varian Prepstar model SD-1 pump A and B, a model 330 PDA detector, and a model 410 autosampler. Samples were analyzed using a phenomenex Luna $(5 \mu \mathrm{m}, 150 \times 4.6 \mathrm{~mm})$. Solvents A and B were water with $0.1 \%$ o-phosphoric acid (85\%) and acetonitrile, respectively. For alkamides, at $\mathrm{t}=0 \mathrm{~min}, \mathrm{~A}$ : $\mathrm{B}=50: 50$; at $\mathrm{t}=18 \mathrm{~min}, \mathrm{~A}: \mathrm{B}=0: 100$; and at $\mathrm{t}=23 \mathrm{~min}, \mathrm{~A}: \mathrm{B}=0: 100$; flow rate was 1 $\mathrm{mL} \cdot \mathrm{min}^{-1}$; and compounds were detected by UV absorption at $260 \mathrm{~nm}$. For cichoric acid, at $\mathrm{t}=0 \mathrm{~min}, \mathrm{~A}: \mathrm{B}=90: 10$; at $\mathrm{t}=25 \mathrm{~min}, \mathrm{~A}$ : $\mathrm{B}=75: 25$; at $\mathrm{t}=26 \mathrm{~min}, \mathrm{~A}: \mathrm{B}=0: 100$; and at $\mathrm{t}=33 \mathrm{~min}, \mathrm{~A}: \mathrm{B}=0: 100$; flow rate was 1 $\mathrm{mL} \cdot \mathrm{min}^{-1}$; and compound was detected by UV absorption at $330 \mathrm{~nm}$.

Alkamides and cichoric acid were identified by comparison of retention times and UV profiles of standards (described below) at 260 nmand $330 \mathrm{~nm}$, respectively. The concentration of each compound in the extract was calculated by using the observed absorbance divided by the average of absorbance per weight of the corresponding standard compound. Alkamides 8 and 9 were quantified against the alkamides 8 and 9 reference standard, while the other alkamides were quantified against alkamide 11. Concentrations were expressed as $\mathrm{mg} \cdot \mathrm{g}^{-1}$ of dry weight of the plant material.

External standards used for the HPLC analysis, dodeca-2E,4E,8Z,10E-tetraenoic acid isobutylamide (8), dodeca-2E,4E,8Z,10Ztetraenoic acid isobutylamide (9), dodeca2E,4E-dienoic acid isobutylamide (11), and cichoric acid, were isolated and purified from the roots of E. angustifolia and the aerial parts of E. purpurea by column chromatography and further preparative HPLC on a Varian microscorb C 18 column $(250 \times 41.4 \mathrm{~mm})$. Chemical structures of these compounds were verified by comparison of ${ }^{1} \mathrm{HNMR}$ spectra and MS data with those in previous reports (Bauer et al., 1988b, 1989). The pure alkamides were mixed and dissolved in methanol to prepare three standard mixtures at different concentrations. Nine injections were given for each standard mixture. The calibration curve was based on the average of absorbance per weight $(\mathrm{mAU} / \mu \mathrm{g})$ of alkamides $(8,9$, and 11$)$ at UV $260 \mathrm{~nm}$ and was expressed as a regression equation. Coefficients of variation were $6.63 \%$ and $1.41 \%$ for alkamides 8,9 , and 11 , respectively. The pure cichoric acid was also dissolved in methanol to prepare three standards at different concentrations. The calibration curve was

Table 1. Contents and comparisons of alkamides (alk) and cichoric acid (cic) in the roots (R) and the nearly matured seed heads $(\mathrm{H})$ of Echinacea purpurea $(\mathrm{n}=30$ plants).

\begin{tabular}{|c|c|c|c|}
\hline Type & $\begin{array}{c}\text { Mean } \pm \text { SD } \\
\left(\mathrm{mg} \cdot \mathrm{g}^{-1}, \text { dry wt }\right)\end{array}$ & Range & $\%$ \\
\hline $\mathrm{R}$ (total alk) & $14.4 \pm 6.41$ & $5.02-28.67$ & \\
\hline $\mathrm{H}$ (total alk) & $1.54 \pm 0.69$ & $0.62-3.42$ & \\
\hline $\mathrm{R}($ alk 8/9²) & $1.12 \pm 0.92$ & $0.23-4.28$ & \\
\hline $\mathrm{H}(\mathrm{alk} 8 / 9)$ & $1.36 \pm 0.60$ & $0.58-2.89$ & \\
\hline $\mathrm{R}(\mathrm{cic})$ & $8.95 \pm 6.46$ & $2.65-37.52$ & \\
\hline $\mathrm{H}(\mathrm{cic})$ & $10.9 \pm 6.61$ & $2.03-31.58$ & \\
\hline \multicolumn{4}{|l|}{ Comparison } \\
\hline $\mathrm{H}$ (total alk):R (total alk) & & & 11 \\
\hline R (alk 8 and 9):R (total alk) & & & 8 \\
\hline H (alk 8 and 9): H (total alk) & & & 88 \\
\hline $\mathrm{H}$ (alk 8 and $9: \mathrm{R}$ (alk 8 and 9 ) & & & 121 \\
\hline $\mathrm{H}(\mathrm{cic}): \mathrm{R}(\mathrm{cic})$ & & & 122 \\
\hline
\end{tabular}

${ }^{2}$ Dodeca-2E, 4E, 8Z, 10E-tetraenoic acid isobutylamide and dodeca-2E, 4E, 8Z, 10Z-tetraenoic acid isobutylamide (alkamides 8 and 9).

Table 2. Contents and comparisons of alkamides (alk) and cichoric acid (cic) in the roots ( $\mathrm{R}$ ) and the young tops $(\mathrm{T})$ of Echinacea purpurea $(\mathrm{n}=30$ plants).

\begin{tabular}{|c|c|c|c|}
\hline Type & $\begin{array}{c}\text { Mean } \pm \text { SD } \\
\left(\mathrm{mg} \cdot \mathrm{g}^{-1}, \text { dry wt }\right)\end{array}$ & Range & $\%$ \\
\hline$\overline{\mathrm{R} \text { (total alk) }}$ & $14.81 \pm 5.98$ & $6.4-27.06$ & \\
\hline $\mathrm{T}$ (total alk) & $0.77 \pm 1.00$ & $0.22-5.25$ & \\
\hline $\mathrm{R}\left(\right.$ alk $\left.8 / 9^{z}\right)$ & $1.62 \pm 1.24$ & $0.4-4.28$ & \\
\hline $\mathrm{T}($ alk 8/9) & $0.59 \pm 0.84$ & $0.16-4.45$ & \\
\hline $\mathrm{R}$ (cic) & $8.41 \pm 4.45$ & $2.42-19.83$ & \\
\hline $\mathrm{T}(\mathrm{cic})$ & $18.88 \pm 11.52$ & $4.79-38.55$ & \\
\hline \multicolumn{4}{|l|}{ Comparison } \\
\hline $\mathrm{T}$ (total alk):R (total alk) & & & 5 \\
\hline $\mathrm{R}$ (alk 8 and 9 ):T (total alk) & & & 11 \\
\hline $\mathrm{T}$ (alk 8 and 9): T(total alk) & & & 77 \\
\hline $\mathrm{T}$ (alk 8 and 9):R (alk 8 and 9) & & & 36 \\
\hline $\mathrm{T}(\mathrm{cic}): \mathrm{R}(\mathrm{cic})$ & & & 224 \\
\hline
\end{tabular}

${ }^{2}$ Dodeca-2E, 4E, 8Z, 10E-tetraenoic acid isobutylamide and dodeca-2E, 4E, 8Z, 10Z-tetraenoic acid isobutylamide (alkamides 8 and 9). 
Table 3. Correlations of alkamides (alk) and cichoric acid (cic) contents between the roots and the nearly matured seed heads (NMSH) (R and H), between the roots and the young tops ( $\mathrm{R}$ and $\mathrm{T})$, and in the roots, the NMSH, and the young tops of Echinacea purpurea ( $\mathrm{n}=30$ plants).

\begin{tabular}{lccccc}
\hline & $\begin{array}{c}\text { Total } \\
\text { Parameter }\end{array}$ & $\begin{array}{c}\text { Alk } \\
8 \text { and } 9\end{array}$ & Cic & $\begin{array}{c}\text { Alk } \\
\text { and cic }\end{array}$ & $\begin{array}{c}\text { Total alk } \\
\text { and alk } 8 \text { and } 9^{\mathrm{y}}\end{array}$ \\
\hline R and H & $0.0792^{\mathrm{NS}}$ & $-0.1670^{\mathrm{NS}}$ & $-0.0032^{\mathrm{NS}}$ & $0.0438^{\mathrm{NS}}$ & \\
R and T & $-0.2182^{\mathrm{NS}}$ & $0.0353^{\mathrm{NS}}$ & $-0.4363^{*}$ & $0.4894^{* *}$ & \\
R & & & $-0.1999^{\mathrm{NS}}$ & $0.4827^{* *}$ \\
$\mathrm{~T}$ & & & $-0.1873^{\mathrm{NS}}$ & $0.9844^{* *}$ \\
$\mathrm{H}$ & & & $-0.1845^{\mathrm{NS}}$ & $0.9705^{* *}$ \\
\hline
\end{tabular}

${ }^{\mathrm{z}}$ For correlation between $\mathrm{R}$ and $\mathrm{H}$ or $\mathrm{R}$ and $\mathrm{T}$, alkamides were from the roots.

yDodeca-2E, 4E, 8Z, 10E-tetraenoic acid isobutylamide and dodeca-2E, 4E, 8Z, 10Z-tetraenoic acid isobutylamide (alkamides 8 and 9 ).

NS,*,** Nonsignificant or significant at $P<0.05$ or 0.01 , respectively.

the average content of alkamides 8 and 9 in the roots was similar to that in the NMSH, and only about two times higher than that in the young tops (Tables 1 and 2), indicating that the large differences in total alkamides between roots and aboveground parts were mainly due to differences in the production of the non-tetraene alkamides in these plant parts. In about $20 \%$ of the NMSH or the young top samples only the tetraene alkamides ( 8 and 9) were detected in this investigation. For cichoric acid, the young tops contained nearly two times more of this compound than did the roots.

Large variation in the content of these phytochemicals has been observed previously in $E$. purpurea. The range of cichoric acid in roots (recorded as percent dry weight) varied between 1.7 and 2.3 in different seasons (Perry et al., 2001), between 0.5 and 0.8 by different plant age or population (Binns et al., 2002b), and has been recorded as high as 4.0 (Bergeron et al., 2000). A similar variation was observed in tops in these studies. For total alkamides, the reported range in variation (percent dry weight) was between 0.12 and 1.21 in root samples and between 0.02 and 0.39 in aboveground parts (Wills and Stuart, 1999), and tetraene alkamides ( 8 and 9 ) varied from 0.03 to 0.4 in tops and from 0.004 to 0.6 in roots (Bauer and Remiger, 1989; Binns et al., 2002b; Bergeron et al., 2000; Perry et al., 2004; Rogers et al., 1998). These differences could be influenced by genetic differences in populations (Binns et al., 2002b), variation in locations and cultural practices (Berti et al., 2002; Dou et al., 2001; Parmenter and Littlejohn, 1997; Perry et al., 2004), plant developmental stages (Perry et al., 2004; Stuart and Wills, 2000), timing of sample collection, or preparation methodology, acting individually or in combination. Nevertheless, theses studies demonstrated that there are considerable natural variations in the levels of phytochemical contents in $E$. purpurea populations, which could be utilized in genetic improvement of this species.

Although the results of previous studies hint at the possibility of useful genetic variation that might be harnessed in the genetic improvement of $E$. purpurea, past results were not based upon experimental designs or samplecollection methods intended to evaluate the genetic contribution to overall variation. Studies employing molecular markers (Baum et al., 1999; Kapteyn et al., 2002) to evaluate genetic diversity in Echinacea suggested that there was greater variation within a population than among populations. In this study it was our desire to use plant materials generated from seeds from different sources to evaluate overall variation among the cultivated accessions. No significant deviations were noted among populations generated from these five sources for the concentrations of alkamides or cichoric acid.

The results of our correlation analyses are presented in Table 3 . No significant correlations were measured between the root and the NMSH for total alkamides, alkamides 8 and 9 , cichoric acid, nor between root alkamides and cichoric acid from the NMSH, or between the root and the young tops for total alkamides and alkamides 8 and 9, indicating nearly independent production in roots and aboveground parts for these phytochemicals. The levels of total alkamides and that of alkamides 8 and 9 were strongly associated in each of the plant parts tested.

A significant negative correlation $(-0.44$, $P<0.05)$ between the root and young tops for cichoric acid concentration was unexpected, since translocation of cichoric acid among plant parts has been suggested based on studies conducted in Australia and New Zealand, in which researchers observed significant positive correlations between the chemical levels in roots and tops (Perry et al., 2004). However, their correlations were based on observations from the two plant parts as a whole taken in different seasons, which would not necessarily be applicable to the relationship in individual plants. The negative correlation observed in our study indicates that it may be difficult for breeders to increase the content of cichoric acid in both roots and aboveground parts simultaneously in E. purpurea.

Observed relationships between total alkamides and cichoric acid were interesting. A strong, positive correlation $(0.49, P<0.01)$ was measured between total alkamides in the roots and cichoric acid in the young tops, but weak non-significant, negative correlations were noted within the roots $(-0.2)$, the NMSH $(-0.18)$ and the young tops $(-0.19)$ between the two phytochemicals. If one also takes the negative correlation for cichoric acid concentration between the roots and the young tops into consideration, the three relationships (positive between the total alkamides in roots and cichoric acid in the young tops, negative between the roots and the young tops for cichoric acid, and negative within plant parts for total alkamides and cichoric acid) seem to be mutually supported. These interacting relationships may suggest that although some of the between-root and top relationships mentioned earlier look to be independent upon first glance, for Echinacea breeding, it may be more desirable to focus on developing cultivars that will produce high yields of alkamides in roots and of cichoric acid in tops than on cultivars that will be highly productive for one of the chemicals in both below and aboveground portions of the plant or for both classes of phytochemicals in either of the two parts.

Our results provide further support to previous reports that there is considerable variation in alkamide and cichoric acid content in $E$. purpurea populations. Although there has been very limited information available on the genetics of Echinacea (reviewed by McKeown, 2004), these large content variations in alkamides and cichoric acid may suggest that a great potential exists for genetic improvement of this species for medicinal purposes. The observations on the correlation relationships could be useful in making this endeavor.

\section{Literature Cited}

Bauer, R. 1999. Chemistry, analysis and immunological investigations of Echinacea phytopharmaceuticals, p. 41-88. In: H. Wagner (ed.). Immunomodulatory agents from plants. Birkhauser Verlag, Basel.

Bauer, R. 2000. Chemistry, pharmacology and clinical application of echinacea products, p. 44-74. In G. Mazza, and B.D. Oomah (eds.). Herbs, botanicals and teas. Technomic Publ. Co. Inc., Lancaster, $\mathrm{Pa}$.

Bauer, R., K. Jurcic, J. Puhlmann, and H. Wagner. 1988a. Immunological in vivo and in vitro examinations of Echinacea extracts. Arzneim. Forsch. 38:276-281.

Bauer, R., P. Remiger, and H. Wagner. 1988b. A1kamides from the roots of Echinacea purpurea. Phytochemistry 27:2339-2342.

Bauer, R. and P. Remiger. 1989. TLC and HPLC analysis of alkamides in Echinacea drugs. Planta Medica 55:367-371.

Bauer, R., P. Remiger, and H. Wagner. 1989. Alkamides from the roots of Echinacea angustifolia Phytochemistry 28:505-508.

Bauer, R. and H. Wagner. 1991. Echinacea species as potential immunostimulatory drugs, p. 253-321. In H. Wagner and N.R. Farnsworth (eds.). Economic and medicinal plant research. vol. 5. Academic Press, New York.

Baum, B.R., S.E. Binns, S. Mechanda, and J.T. Arnason. 1999. The Echinacea germplasm enhancement project. Proceedings of the 1999 International Echinacea Symposium. Amer. Herbal Products Assn., Silver Springs, Md.

Bergeron, C., J.F. Livesey, D.V.C. Awang, J.T. Arnason, J. Rana, B.R. Baum, and W. Lechamo. 2000. A quantitative HPLC method for the quality assurance of Echinacea products on the North American market. Phytochem. Anal. 11:207-215.

Berti, M., R. Wilckens, S. Fischer, and F. Hevia. 2002. Effect of harvest season, nitrogen, phosphorus and potassium on root yield, echinacoside and alkamides in Echinacea angustifolia L. in Chile. Acta Hort. 576:303-310.

Binns, S.E., B.R. Baum, and J.T. Arnason. 2002a. A taxonomic revision of Echinacea (Asteraceae: Heliantheae). Syst. Bot. 27:610-632.

Binns, S.E., J.T. Arnason, and B.R. Baum. 2002b. Phytochemical variation within populations of 
Echinacea angustifolia (Asteraceae). Biochemical Syst. Ecol. 30:837-854.

Bodinet, C. and N. Beuscher. 1991. Antiviral and immunological activity of glycoproteins from Echinacea purpurea radix. Planta Medica 57:33-34.

Bodinet, C., I. Willigmann, and N. Beuscher. 1993. Host-resistance increasing activity of root extracts from Echinacea species. Planta Medica 59:672-673.

Bone, J. 2004. Echinacea: Quality, uses, and immunomodulating activity from a phytotherapist's perspectives, p. 203-213. In: S.C. Miller and H. Yu (eds.). Echinacea: The genus Echinacea. CRC Press, Boca Raton, Fla.

Brevoort, P. 1998. The booming U.S. botanical market: A new overview. HerbalGram 44:33-48.

Chicago Botanic Garden. 2001. Perennial plant breeding. http://www.chicago-botanic.org/research/breeding/perennial breeding.html

Dou, D., S. Cui, Y. Cao, Y. Yan, and S. Fei. 2001. Assaying of cichoric acid in introducing plant $E c h i-$ nacea purpurea. Zhongcaoyao 32:987-988.

Foster, S. 1991. Echinacea: Nature's immune enhancer. Healing Arts Press, Rochester, Vt.

Galambosi, B. 2004. Cultivation in Europe, p. 29-52. In: S.C. Miller and H. Yu (eds.). Echinacea: The genus Echinacea. CRC Press, Boca Raton, Fla.

Goel, V., C. Chang, J.V. Sloma, R. Barton, R. Bauer, R. Gahler, and T.K. Basu. 2002. Alkylamides of Echinacea purpurea stimulate alveolar macrophage function in normal rats. Intl. J. Immunopharmacol. 2:381-387.

Goel, V., R. Lovlin, R. Barton, M.R. Lyon, R. Bauer, T.D.G. Lee, and T.K. Basu. 2004. Efficacy of a standardized Echinacea preparation (EchinilinTM) for the treatment of the common cold: a randomized, double-blind, placebo-controlled trial. J. Clin. Pharmacol. Ther. 29:75-83.

Hawks, K. 2002. 'Kim’s Knee High'. Plant Var. J. 15:34-35.

Kapteyn, J., P.B. Goldsbrough, and J.E. Simon. 2002. Genetic relationships and diversity of commercially relevant Echinacea species. Theor. Appl. Genet. 105:369-376.

Kindscher, K. 1989. Ethnobotany of purple conflower (Echinacea angustifolia, Asteraceae) and other Echinacea species. Econ. Bot. 43:498-507.

Letchamo, W., J.Livesey, T.J.Arnason, C. Bergeron, and V.S. Krutilina. 1999. Cichoric acid and isobutylamide content in Echinacea purpurea as influenced by flower developmental stages, p. 494-498. In: J. Janick (ed.). Perspectives on new crops and new uses. ASHS Press, Alexandria, Va.

Letchamo, W., L.V. Polydeonny, N.O. Gladisheva, T.J. Arnason, J. Livesey, and D.V.C. Awang. 2002. Factors affecting Echinacea quality, p. 514-521. In: J. Janick and A. Whipkey (eds.). Trends in new crops and new uses. ASHS Press, Alexandria, Va.

Li, T.S.C. 1998. Echinacea: Cultivation and medicinal value. HortTechnology 8:122-129.

McDougall, B., P.J. King, B.W. Wu, Z. Hostomsky, M.G. Reinecke, and W.E. Robinson. 1998. Dicaffeoylquinic and dicaffeoyltartaric acid are selective inhibitors of human immunodeficiency virus type 1 integrase. Antimicrob. Agents Chemo. 42:140-146.

McGregor, R.L. 1968. The taxonomy of the genus Echinacea (Compositae). University of Kansas
Science Bulletin 48:113-142.

McKeown, K.A. 2004. A review of preliminary Echinacea genetics and the future potential of genomics, p. 13-20. In: S.C. Miller and H. Yu (eds.). Echinacea: The genus Echinacea . CRC Press, Boca Raton, Fla.

Parnham, M.J. 1996. Benefit-risk assessment of the squeezed sap of the purple coneflower (Echinacea purpurea) for long term oral immunostimulation. Phytomedicine 3:95-102.

Parmenter, G.A. and R.P. Littlejohn. 1997. Planting density effects on root yield of purple coneflower [Echinacea purpurea (L.) (Moench)]. N.Z. J. Crop Hort. Sci. 25:169-175.

Perry, N.B., E.J. Burgess, and V.L. Glennie. 2001. Echinacea standardization: analytical methods for phenolic compounds and typical levels in medicinal species. J. Agr. Food Chem. 49:1702-1706.

Perry, N.B., R.B.H. Wills, and D.L. Stuart. 2004. Factors affecting Echinacea quality: Agronomy and processing, p. 111-126. In: S.C. Miller and H. Yu (eds.). Echinacea: The genus Echinacea. CRC Press, Boca Raton, Fla.

Rogers, K.L., I.D. Grice, C.J. Mitchell, and L.R. Griffiths. 1998. High performance liquid chromatography determined alkamide levels in Australian-grown Echinacea spp. Austral. J. Expt. Agr. 38:403-408.

Stuart, D.L. and R.B.H. Wills. 2000. Alkylamide and cichoric acid levels in Echinacea purpurea tissues during plant growth. J. Herbs Spices Med. Plants 7:91-101.

Wills, R.B.H. and D.L. Stuart. 1999. Alkylamide and cichoric acid levels in Echinacea purpurea grown in Australia. Food Chem. 67:385-388. 